\title{
Alcohol craving in relation to coping with stress and satisfaction with life in the addicted
}

\section{BACKGROUND}

The present study aimed at finding any relation between alcohol craving and strategies of coping with stress and satisfaction with life in the addicted. Until now, studies have shown that generalized deficits in coping with stress, and the dominance of avoidance strategies, are significantly related to the increase of the risk of addiction and the course of this disease. This relation, which could link strategies of coping with stress and quality of life with experiencing alcohol craving, has only been explained to a small extent. Also, the role of gender in explaining these relations is ambiguous.

\section{PARTICIPANTS AND PROCEDURE}

The study was conducted in a group of 550 addicted subjects in out-patient or in-patient treatment (396 men and 114 women). In the present study the following instruments were used: the Craving Typology Questionnaire by Marinotti et al., the Yale-Brown Obsessive-Compulsive Drinking Scale by Modell et al., the Mini-Cope by Carver et al., SADD by Reistrick et al., and the Satisfaction with Life Scale by Diener et al. Statistical correlational analysis

\begin{abstract}
and structural equations were applied, namely partial least squares path modelling (PLS-PM).
\end{abstract}

RESULTS

There are two types of links between craving and strategies of coping with stress among the addicted. The first dominating type is pointing at casual link between ineffective strategies of coping with stress and craving. The other weaker type indicates the diminishing influence of effective strategies of coping with stress on alcohol craving. Life satisfaction lowers alcohol craving.

\section{CONCLUSIONS}

Effective strategies of reacting to stress, together with life satisfaction, protect against increase of alcohol craving. Severity of dependence is an important factor which moderates the influence of strategies of coping with stress on alcohol craving.

\section{KEY WORDS}

alcohol craving; strategies of coping with stress; life quality; structural modelling PLS-PM

ORgANizATION - 1: Department of Social Prevention and Rehabilitation, Jan Kochanowski University, Kielce, Poland .

2: Świętokrzyski Prevention and Education Centre, Kielce, Poland · 3: Addictions Treatment Ward, Doctor Barbara

Borzym Independent Regional Public Centre of Psychiatric Health Care, Radom, Poland · 4: Department of Health

Psychology, Institute of Psychology, University of Lodz, Lodz, Poland · 5: Department of Psychiatric Nursing,

Nicolaus Copernicus University in Torun, Collegium Medicum in Bydgoszcz, Poland · 6: The Blessed Rafał Chyliński

Municipal Centre of Public Health, Lodz, Poland · 7: Department of Cognitive Science, Institut of Psychology,

Faculty of Educational Sciences, University of Lodz, Lodz, Poland

AUthors' CONtributions - A: Study design - B: Data collection · C: Statistical analysis · D: Data interpretation ·

E: Manuscript preparation · F: Literature search · G: Funds collection

Corresponding Author - Krzysztof Gąsior, Ph.D., Świętokrzyski Prevention and Education Centre, 65 Nowaka Jeziorańskiego Str., 25-432 Kielce, Poland, e-mail: gasior@profilaktyka.com

to Cite this ARTICle - Gąsior, K., Biedrzycka, A., Chodkiewicz, J., Ziółkowski, M., Czarnecki, D., Juczyński, A.,

\& Nowakowska-Domagała, K. (2016). Alcohol craving as related to coping with stress and satisfaction with life in

the addicted. Health Psychology Report, 4(1), 65-78. doi: 10.5114/hpr.2016.54399

RECEIVED 01.04.2015 - REVIEWED 29.04.2015 • ACCEPTED 29.05.2015 • PUBLISHED 03.10.2015 


\section{BACKGROUND}

Experiencing alcohol craving is an important factor in the development and maintenance of a dependence. It is a source of strong discomfort and suffering, and also a symptom of alcoholism which belongs to the major diagnostic criteria of the dependence (ICD-10, DSM-V) (Casey, Adamson, Shevlin, \& McKinney, 2012). It should be noted that the notion of "alcohol craving" pertains exclusively to the addicted, and it is used to define a state which is characterized by intense thinking, with an increased and hard-to-resist willingness to drink or to experience the effects of drinking (among others: Tiffany \& Conklin, 2000).

Among many theories regarding psychological determinants of dependencies, there should be highlighted those concepts in which the growth of the role of alcohol as a motivating stimulus is presented as a basic component of a dependence (Altman et al., 1996; Di Chiara, 1998; Hughes \& Bickel, 1997; Koob, 1996). In behavioural concepts special attention is given to the effect of positive reinforcement, which determines one's striving to have another contact with the stimulus (alcohol). On the basis of the mechanism of instrumental conditioning a behaviour is reinforced by its consequences (Altman et al., 1996; Samson, 1986). A reinforcing stimulus not only provides a specific benefit (a reward) but also influences the need of seeking another contact with the stimulus (motivation). An activity that is understood this way lies in an inborn or learned pattern of behaviours which are primarily aimed at repeating (or avoiding) a sequence of stimuli perceived as favourable (or not) for a person who is exposed to situations related to drinking alcohol (Di Chiara, 1995).

Motivational behaviours may start to have a decisive role when the effectiveness of positive reinforcement becomes weaker and weaker (Altman et al., 1996; Mendelson, Scholar, Mello, Teoh, \& Scholar, 1998; Wolffgramm \& Heyne, 1995). This phenomenon occurs in a moment of well-advanced alcoholism and decreased tolerance. Then an addicted person is focused on searching for alcohol, though its rewarding value is becoming weaker while negative reinforcement is becoming more important. This is linked with a subjective feeling of craving with varied intensity in drinking that leads to a state of saturation, which results in an effect of satisfaction. Due to this, the value of a motivating factor and negative reinforcements increases in the alcohol-addicted, contrary to persons who control their drinking (Altman et al., 1996; Di Chiara, 1995; Hughes \& Bickel, 1997; Koob, 1996).

Learning based on instrumental conditioning, where drinking alcohol is one of the behaviourally learned ways of coping with stress, may use two mechanisms: the mechanism of positive reinforce- ment and the mechanism of negative reinforcement. In the first case, drinking provides an individual with some specific benefits; in the latter case, an individual drinks alcohol to avoid a psychological discomfort. Both mechanisms are associated with activating the "reward system" in the brain, and the process of striving for a psychoactive substance becomes to a large extent an unconscious drive (Kostowski, 2005).

More conscious processes, which are also based on learning, are motivational processes. Motivation is the basis for human activity. It is a regulatory process that controls activity so as to achieve a specific goal (Chodkiewicz, 2013). Numerous studies have shown that people have different levels of adaptive abilities, which influence the perceived quality of life and their motivation to take action (Diener \& Lucas, 2006). Striving for alcohol and drinking are often determined by the need to achieve a specific goal, e.g. reduction of tension. Such behaviours become learned strategies of coping with difficult situations and stress, and they also restore balance in persons who have no other, more constructive ways of managing problems and the surrounding reality. This is consistent with the assumptions contained in the stress theory by Lazarus and Folkman, in which it is stated that stress appears in situations of lack of balance between demands from an environment and remedial possibilities of an individual (Lazarus, 1965; Lazarus \& Folkman, 1984).

Mechanisms that are responsible for the appearance of relations between alcohol craving and stress are not thoroughly known. Among studies in animals and people, it has been stated that stress is one of the major factors that determine striving for alcohol, continued drinking, and the occurrence of relapses after periods of abstinence (Sinha, 2013; De Witt, 1996; Le et al., 1998; Stewart, 2000). Many authors try to explain these relations by pointing out the marked tendency of using alcohol to reduce tension and anxiety (Sinha, Fox, Hong, Bhagwagar, \& Siedlarz, 2009; Cappell, 1972; Conger, 1951; Hodgson, Stockwell, \& Rankin, 1979). Moreover, numerous studies on relations between dependence and stress show evidence that with development and deepening of a dependence there is also an increase in deficits in adaptive and constructive ways of coping with stress, which lowers life quality (Cierpiałkowska \& Ziarko, 2010; Yoon, Kim, Thuras, Grant, \& Westermeyer, 2006). Therefore, the depth of dependence plays a significant role in the way of reacting to stress in the addicted which correlates with their level of life quality (among others: Morgan, Landron, \& Lehert, 2004).

In chronic drinkers, with seriously advanced alcohol dependence, there are observed losses in all areas of personal, family, and social life, which also means a decrease in their life quality (Ryff, 1989). Cognitive aspects of satisfaction with life as a whole regard satisfaction with its particular areas. A subjective 
balance of positive and negative emotional states, together with a cognitive assessment, makes life quality as perceived by an individual (Myers \& Diener, 1995). Sociodemographic variables (age, sex, education) do not display any explicit dependencies with the quality of life (Diener, 1984). Self-esteem presents a markedly stronger predicator than sociodemographic variables (Cheng \& Furnham, 2003).

When analysing literature on the subject, one can note that, up to now, researchers have shown relatively little interest in the topic of life quality in the addicted. However, it is possible to quote studies by Volk, Steinbauer, and Cass (1997) and Daeppen, Krieg, Burnand, and Yersin (1998), in which it has been confirmed that dependent persons are characterized by a significantly lower life quality as compared to the general population and to persons suffering from other chronic diseases. Also an analysis of publications from the years 1993-2004, made by Donovan, Mattson, Cisler, Longabaugh, and Zweben (2005), indicates a clearly lowered level of life quality in the alcohol-addicted persons. Similar results were obtained by Chodkiewicz (2012) in a group of addicted persons in Poland. Yet, until now no studies have been performed regarding the relations between craving and life quality in alcoholics.

Analysing the literature on alcohol craving reveals that it is a very complex phenomenon and it is hard to define (see survey by Chodkiewicz, 2014). One of the more inspiring models of craving that has appeared recently is the model developed by Verheul, Van Den Brink, and Geerlings (1999). The authors suggest the existence of three paths that lead to craving - a path related to the need of reward (craving stimulated and strengthened by alcohol, more frequent in men), a path related to the desire of relief (craving related to reduction of tension and excessive reactivity to stress), and a path related to the obsessive-compulsive aspect of seeking alcohol (lack of control over intrusive thoughts and compulsive behaviours that are linked with the search for alcohol). All three aspects of craving coexist in the addicted, but one of them may dominate (Martinotti et al., 2013; Skinner \& Aubin, 2010).

In the course of development of dependence, the more complex motivational behaviours become more important. This process, which is strongly linked with conditioning alcohol as a mediating factor in adaptive mechanisms, especially regarding the ways of coping with stress (Carver, Scheier, \& Weintraub, 1989; Terelak \& Dzięgielewska, 2011; Marlat \& Gordon, 1985), is undoubtedly related to life quality of an addicted person. However, what are the relations of alcohol craving with ways of reacting to stress and life quality? No satisfactory answers to this questions are available. Moreover, these relations seem to differ significantly for men and women. In the study by Chaplin, Hong, Bergquist, and Sinha (2008), it is sug- gested that alcohol craving is related more strongly to lowered mood and anxiety in women, and to general emotional tension and the search for satisfaction in men (reward motivation and emotional stress systems). This result shows that women and men react to stress and craving in different ways.

The current study aims at searching for an answer to the question regarding dependencies of alcohol craving with strategies of coping with stress and quality of life. Recent studies have indicated that generalised deficits in coping with stress, and dominance of avoidance strategies, are significantly related to the increase of the risk of dependence or even to alcohol disease (Terelak \& Dzięgielewska, 2011). The role of gender in explaining these relations seems less clear. Taking into account the above statements, the following research questions have been formed: - what are the relations of alcohol craving with strategies of coping with stress and satisfaction with life?

- are there any gender-related differences regarding the relations described above?

- does severity of dependence play a role in the relations between alcohol craving, stress, and life quality?

\section{PARTICIPANTS AND PROCEDURE}

The study was conducted in a group of out-patients and in-patients treated in the centres in Bydgoszcz, Kielce, Łódź, Morawica, Pabianice, and Radom. All the examined patients had alcohol dependence diagnosed (ICD-10) by a psychiatrist. The examination was made in the $3^{\text {rd }}$ to $6^{\text {th }}$ week of the therapy so as to avoid the effects of abstinence syndrome. The research procedure was approved by the Committee for Bioethics of Scientific Research at the University of Lodz (5/KBBN-UŁ/I/2014). The study took place between June and October in 2014. Five hundred and fifty subjects were examined, but after rejecting incomplete questionnaires, 510 persons were accepted for analysis. The examined group comprised 396 men and 114 women. The mean age was $44.15(S D=11.25$, from 21 to 76 ).

\section{EXAMINATION TOOLS}

The Craving Typology Questionnaire (CTQ) by Martinotti et al. (2013), which was based on the psychobiological three-path model (Verheul et al., 1999), consists of 20 statements that refer to drinking alcohol related to the need of reward, the desire of relief, and as a consequence of compulsive behaviours and giving in to obsessive thoughts. The method is characterized by good psychometric properties Cronbach's $\alpha$ coefficient ranges from .81 to .83 , and
Alcohol craving and stress 
Krzysztof Gąsior, Agata Biedrzycka, Jan Chodkiewicz, Marcin Ziółkowski, Damian Czarnecki, Artur Juczyński, Katarzyna NowakowskaDomagała confirmatory and exploratory factor analysis has confirmed the existence of the three adopted factors (Martinotti et al., 2013). The Polish version of the tool has satisfactory psychometric properties (Chodkiewicz et al., in preparation).

The Yale-Brown Obsessive Compulsive Scale Modified to Reflect Obsessions and Compulsions Related to Heavy Drinking (Modell, Glaser, Mountz, Schmaltz, \& Cyr, 1992) was designed to measure the intensity of obsessive and compulsive thoughts and behaviours regarding alcohol in persons who overuse or are addicted. Studies show differences between dependent and nondependent persons with regard to all the scale questions. The authors have not made a factor analysis, which could confirm or exclude the existence of the two adopted factors. In the study the Polish version of the tool was used; it has good psychometric properties (Nowakowska-Domagała et al., in print).

The MINI-COPE by Carver et al., adapted by Juczyński (Juczyński \& Ogińska-Bulik, 2009; Carver et al., 1989; Litman, 2006), consists of 26 statements that belong to 13 strategies of coping with stress (2 statements in each category). The method is applied mostly to measure dispositional coping in situations in which a strong stress is experienced.

The Satisfaction with Life Scale (SWLS) (Diener, Emmons, Larsen, \& Griffin, 1985), adapted by Juczyński (2009), comprises five statements for which an examinee assesses to what extent each of them pertains to his/her day-to-day life. The score is the general indicator of feeling satisfaction with life.

The Short Alcohol Dependence Data Questionnaire (SADD) (Raistrick, Dunbar, \& Davidson, 1983) to assess severity of a dependence, in the Polish adaptation by Ziółkowski (1994), was also used.

Analysis of the obtained results was performed using STATISTICA v.10 and WarpPLS 5.0. (www. scriptwarp.com).

Descriptive statistics were carried out first. Next, distributions of the particular variables and dependencies among them were analysed. Correlational analysis referred to dependencies between alcohol craving and strategies of reacting to stress, considering gender. The obtained results showed significant correlations among variables on the one hand, and far from normal distributions of the data and nonlinear dependencies among variables on the other hand. This situation necessitated the selection of more advanced analytical methods and pointed to the sense of using the partial least squares method (PLS-PM) in designing and computing a structural model.

Methods based on structural modelling (SEM) have been developing dynamically since the 1970s, and this has introduced a significant change in ways of using statistics in social sciences, including psychology (Januszewski, 2011). SEM not only allows formal capture of a measurement bias, but it also slackens some of the restrictive assumptions of the variance analysis (Konarski, 2009). The statistical strategy of SEM becomes primarily aimed at explaining a structure of covariance (correlation) of variables by means of building a theoretical model of dependencies. SEM is mainly a method of exploring, testing, and verifying models (theories) on the basis of their prediction results. Yet, in its classical version it contains a few significant assumptions that are difficult to fulfil. This applies particularly to linear dependencies among variables, normal distribution of the data, or sample size. In recent years a number of methods and ways of solving these problems have been proposed. The use of partial least squares path modelling (PLS-PM), which gains more and more applications in social sciences research (Espozito Vinzi, Chin, Henseler, \& Wang, 2010), is one such approach. Structural modelling with SEM is aimed at explaining values of model parameters. It is based on the normal distribution and linear dependencies among variables and on explaining covariance, and the relation between measures and factors is reflective. The PLS-PM method on the other hand is aimed not at estimation but at prediction (McIntosh, Edwards, \& Antonakis, 2014). The PLS-PM method is based on explaining variance, its assumptions are nonparametric, and the relation between measures and factors is both reflective and formative (compare: Przechlewski, 2011). Although SEM still remains a leading method in analyses of psychological data, one can now find applications of PLS-PM in studies of varied clinical groups whose results do not meet the requirements of linearity and normal distribution (compare: Abd-El-Fattah \& Fakhroo, 2012; Hamidizadeh, Koolivand, \& Hajkarimi, 2014; Wilson \& Djamasbi, 2012). It is interesting to note some suggestions by Kock (Kock, 2011; Kock \& Lynn, 2012), who made a statistical program called WarpPLS (www. scriptwarp.com). The tool is promising and is being used more frequently (Berglund, Lystsy, \& Westerling, 2013; Etinger, Šehanović, \& Ribić, 2014; Wilson, Sheetz, Djamasbi, \& Webber, 2014).

\section{RESULTS}

We started working on the results with an analysis of distributions of particular variables in the whole group. The Kolmogorov-Smirnov test with the Lilliefors correction revealed significant divergences from the normal distribution. Thus, there were analysed distributions in the group on account of divergent cases, in order to exclude any measurement biases or mistakes in making a database. As a result of this analysis, 19 divergent cases were deleted. This procedure improved the distributions to a small extent. This will have some consequences in the selection of statistical methods used to examine dependencies among the variables. 
Distributions of the variables on account of gender were also analysed. Also, in this case, significant differences were observed. Next, there was performed an introductory analysis in which values of correlation coefficients between alcohol craving and life satisfaction and strategies of coping were computed (Table 1).

Table 1

Correlation coefficients between coping strategies (Mini-Cope), severity of dependence (SADD), satisfaction with life (SWLS) and craving (CTQ, Yale-Brown)

\begin{tabular}{|c|c|c|c|c|c|}
\hline & Sex & $\begin{array}{l}\text { CTQ: Reward } \\
\text { craving }\end{array}$ & $\begin{array}{l}\text { CTQ: Relief } \\
\text { craving }\end{array}$ & $\begin{array}{l}\text { CTQ: Obses- } \\
\text { sive craving }\end{array}$ & $\begin{array}{c}\text { Y-B: } \\
\text { Overall result }\end{array}$ \\
\hline \multirow{3}{*}{ S1: Active coping } & whole group & $-.20^{* *} \downarrow$ & $-.18^{* *}$ & $-.26^{* *}$ & $-.21^{* *}$ \\
\hline & M & $-.19^{* *}$ & $-.19^{* *}$ & $-.28^{* *}$ & $-.22^{* *}$ \\
\hline & $\mathrm{F}$ & $-.21^{* *}$ & $-.18^{* *}$ & $-.17^{* *}$ & $-.16^{* *}$ \\
\hline \multirow{3}{*}{ S2: Planning } & whole group & $-.20^{* *}$ & $-.19^{* *}$ & $-.27^{* *}$ & $-.19^{* *}$ \\
\hline & M & $-.22^{* *}$ & $-.20^{* *}$ & $-.31^{* *}$ & $-.23^{* *}$ \\
\hline & $\mathrm{F}$ & $-.15^{* *}$ & $-0.16^{* *}$ & $-.16^{* *}$ & -.03 \\
\hline \multirow{3}{*}{ S3: Positive reframing } & whole group & $-.10^{*} \downarrow$ & $-.14^{* *}$ & $-.14^{* *}$ & $-.14^{* *}$ \\
\hline & M & -.08 & $-.14^{* *}$ & $-.19^{* *}$ & $-.15^{* *}$ \\
\hline & $\mathrm{F}$ & $-.21^{*}$ & $-.11^{*}$ & -.02 & $-.11^{*}$ \\
\hline \multirow{3}{*}{ S5: Sense of humour } & whole group & $.13^{* *}$ & .03 & .05 & .02 \\
\hline & M & $.12^{*}$ & .03 & .08 & .05 \\
\hline & $\mathrm{F}$ & .05 & .03 & $-.10^{*}$ & $-.12^{*}$ \\
\hline \multirow{3}{*}{$\begin{array}{l}\text { S7: Seeking emotional } \\
\text { support }\end{array}$} & whole group & $-.15^{* *}$ & $-.10^{*}$ & $-.16^{* *}$ & $-.15^{* *}$ \\
\hline & M & $-.18^{* *}$ & $-.12^{*}$ & $-.15^{* *}$ & $-.16^{* *}$ \\
\hline & $\mathrm{F}$ & -.04 & .01 & $-.18^{* *}$ & $-.13^{*}$ \\
\hline \multirow{3}{*}{$\begin{array}{l}\text { S8: Seeking instrumental } \\
\text { support }\end{array}$} & whole group & .07 & -0.03 & $-0.08 \downarrow$ & $-.14^{* *} \downarrow$ \\
\hline & M & .08 & .05 & $.13^{*}$ & $-.14^{* *}$ \\
\hline & $\mathrm{F}$ & .04 & .01 & .07 & $-.18^{* *}$ \\
\hline \multirow{3}{*}{ S10: Denial } & whole group & $.16^{* *}$ & $.19^{* *}$ & $.23^{* *}$ & $.12^{* *}$ \\
\hline & M & $.18^{* *}$ & $.19^{* *}$ & $.24^{* *}$ & $.16^{* *}$ \\
\hline & $\mathrm{F}$ & $.13^{*}$ & $.16^{* *}$ & $.18^{* *}$ & .01 \\
\hline \multirow{3}{*}{ S11: Venting } & whole group & $.22^{* *} \downarrow$ & $.23^{* * \uparrow}$ & $.21^{* *}$ & $.18^{* *}$ \\
\hline & M & $.18^{* *}$ & $.25^{* *}$ & $.26^{* *}$ & $.22^{* *}$ \\
\hline & $\mathrm{F}$ & $.27^{* *}$ & $.22^{* *}$ & $.16^{* *}$ & .09 \\
\hline \multirow{3}{*}{ S12: Substance use } & whole group & $.28^{* *} \downarrow$ & $.38^{* * \uparrow}$ & $.35^{* * \uparrow}$ & $.37^{* * \uparrow}$ \\
\hline & M & $.28^{* *}$ & $.40^{* *}$ & $.36^{* *}$ & $.39^{* *}$ \\
\hline & $\mathrm{F}$ & $.36^{* *}$ & $.34^{* *}$ & $.33^{* *}$ & $.31^{* *}$ \\
\hline \multirow{3}{*}{$\begin{array}{l}\text { S13: Behavioural disen- } \\
\text { gagement }\end{array}$} & whole group & $.25^{* *} \downarrow$ & $.30^{* * \uparrow}$ & $.37^{* * \uparrow}$ & $.27^{* *}$ \\
\hline & M & $.24^{* *}$ & $.31^{* *}$ & $.36^{* *}$ & $.31^{* *}$ \\
\hline & $\mathrm{F}$ & $.37^{* *}$ & $.26^{* *}$ & $.26^{* *}$ & $.15^{* *}$ \\
\hline \multirow{3}{*}{$\begin{array}{l}\text { SADD: Severity of depen- } \\
\text { dence }\end{array}$} & whole group & $.37^{* *} \downarrow$ & $.38^{* * \uparrow}$ & $.45^{* * \uparrow}$ & $.55^{* * \uparrow}$ \\
\hline & M & $.36^{* *}$ & $.39^{* *}$ & $.45^{* *}$ & $.55^{* *}$ \\
\hline & $\mathrm{F}$ & $.41^{* *}$ & $.35^{* *}$ & $.43^{* *}$ & $.54^{* *}$ \\
\hline \multirow{3}{*}{$\begin{array}{l}\text { SWLS: Satisfaction with } \\
\text { life }\end{array}$} & whole group & $-.19^{* *} \downarrow$ & $-.30^{* *} \downarrow$ & $-.23^{* * \uparrow}$ & $-.26^{* * \uparrow}$ \\
\hline & M & $-.19^{* *}$ & $-.29^{* *}$ & $-.24^{* *}$ & $-.27^{* *}$ \\
\hline & $\mathrm{F}$ & $-.22^{* *}$ & $-.35^{* *}$ & $-.21^{* *}$ & $-.22^{* *}$ \\
\hline
\end{tabular}

Note. $\uparrow$ - as for the absolute value statistically significantly higher correlation in the group of men; $\downarrow$ - as for the absolute value statistically significantly higher correlation in the group of women; ${ }^{*} p \leq .01 ;{ }^{*} p \leq .05 / \uparrow$ significantly higher correlation in men $\downarrow$ significantly higher correlation in women; ${ }^{*} p \leq .01 ;{ }^{*} p \leq .05$. Own source. 
Krzysztof Gąsior, Agata Biedrzycka, Jan Chodkiewicz, Marcin Ziółkowski, Damian Czarnecki, Artur Juczyński, Katarzyna NowakowskaDomagała
The conducted analysis indicates that the craving scales are linked to strategies of coping with stress, satisfaction with life, and severity of dependence by means of numerous correlations that are varied in their strength. All the craving scales have the strongest positive correlations with ineffective strategies of reacting to stress that pertain to avoidance behaviours, i.e. alcohol use, denial, behavioural disengagement, and venting. The strategy of alcohol use correlates most strongly with the following CTQ scales: desire for relief (.40) and obsessions/compulsions (.38). There are also significant correlations with the Yale-Brown Scale (.37). Slightly weaker correlations with all the tools appear in the case of behavioural disengagement (from .35 to .21), and venting (from .24 to .11$)$.

The analyses that were carried out have rendered it possible to distinguish the second group of more effective strategies of coping with stress. In this case, correlations with craving are negative and weaker than those found in the dominating ineffective strategies. They regard mainly active coping (from .25 to .18), planning (.27 to .17), positive reframing (from .19 to .12 ), and support from a partner (from .16 to .11) or support from friends (from .14 to .12). Such strategies of reacting to stress as acceptance, a turn towards religion, sense of humour, and distracting one's attention are either not related at all or slightly related to craving.

The analysis of relations between craving and strategies of coping with stress with regard to gender is interesting. It appears that gender presents an important variable which differentiates those relations. In the case of ineffective strategies of coping with stress, a stronger tendency to alcohol use, behavioural disengagement, and venting are clearly dominant and characteristic in women, especially in the context of experiencing craving that results from the need of reward. Considering drinking obsessions, the support from friends takes an even more significant role in women as compared to men, as measured with the Yale-Brown Scale. In men there is a stronger relation of alcohol use and behavioural disengagement with such craving components as the desire for relief and (next) obsessions/compulsions.

To sum it up, in men such craving components as the desire for relief and drinking obsessions are more strongly related to alcohol use and behavioural disengagement in reaction to stress, while in women such craving components as the need of reward and obsessive thoughts about drinking are more strongly related not only to alcohol use or behavioural disengagement but also to venting emotions. Basically, women and men do not differ regarding relations between craving and effective strategies of reacting to stress. Yet, there exists a statistical tendency in women which indicates a relation between craving and a turn towards religion.
Satisfaction with life is significantly related to craving, as measured with both CTQ and the YaleBrown Scale. The correlations are negative and their strength may be defined at most as moderate or weak. There are no significant differences between women and men in this regard.

As for severity of dependence, it turns out to be strongly related to craving and its varied symptoms (CTQ from .39 to .48; Yale-Brown .57). The strongest correlations apply to obsessions and compulsions that are related to experiencing alcohol craving.

The correlational studies do not explain causal dependencies among the examined variables. In order to define these relations, structural modelling was used.

A path model was built, describing dependencies of alcohol craving with strategies of coping with stress, satisfaction with life, and severity of dependence. In order to build an internal model we used 4 latent variables: alcohol craving (CRAVING), strategies of coping with stress (STRESS), satisfaction with life (SL), and severity of dependence (SD). To build an external model describing observable variables the previously presented tools were used. The constructed model was based on definitions of craving operationalised with CTQ.

The first stage of analyses was aimed at examining the relations between craving measured with CTQ and 13 strategies of coping with stress, and excluding those observable variables that make insignificant relations. The analysis of these dependencies, which was made on the basis of previously conducted assessment of strength and direction of correlations, rendered it possible to define two subgroups of scales related to strategies of coping with stress. The second stage consisted in building more general models which took into consideration relations of craving not only with stress but also with severity of dependence and satisfaction with life.

The results of the first stage of analysis suggested the existence of two groups of correlations (different in their directions) that are connected to strategies of coping with stress: Stress 1 (negative relations): S1, S2, S3, S7, S8, and Stress 2 (positive relations): S9, S10, S11, S12, S13.

\section{THE MODEL OF CRAVING BASED ON THE CONSTRUCT MEASURED WITH CRAVING TYPOLOGY QUESTIONNAIRE}

In this model, craving as a latent variable was described with observable variables that formed $3 \mathrm{sub-}$ scales of CTQ: reacting to stress was defined with Mini-Cope, life satisfaction with SWLS, and severity of dependence with SADD. Relations between latent variables and observable variables were defined as reflective ones. In the model, gender (formative) 
was included as a variable that moderated relations among latent variables. Lack of assumptions about distribution of the observable variables in the PLSPM method leads to using the so-called quality index in the statistical assessment of the model. That is why the PLS-SEM method was named by Wold (after: Tenenhaus, Esposito Vinzi, Chatelin, \& Lauro, 2005) soft modelling, to be differentiated from the classic SEM, which is called hard modelling. The assessments of the model that are most frequently presented regard validity of selection of indicators to describe latent variables, quality of external and internal models, assessment of the model as a whole, and assessment of significance of estimated parameters (Espozito Vinzi, Chin, Henseler, \& Wang, 2010).

The examined model was analysed in two steps. The first step was made after completing the analysis of the external model. The observable variables that presented factor loading below .70 were eliminated. The obtained matrix of factor loadings and cross loadings is presented in Table 2. The first group of observable variables (Stress 1 ) that were negatively related to the latent variable (CRAVING) was made of the following Mini-Cope scales: active coping (S1), planning (S2), and positive reframing (S3). In the literature, these are referred to as effective ways of coping with stress (compare: Juczyński \& Ogińska-Bulik, 2009). The second group of variables (Stress 2) that were positively related to the latent variable (CRAVING) comprised: denial (S10), venting (S11), alcohol use (S12), and behavioural disengagement (S13). These are assessed as ineffective ways of reacting to stress.

Selection validity of the particular variables was confirmed as the calculated loadings exceeded the value of .70 and $p \leq .05$ (compare the threshold value according to Hair et al., 2014). In Table 3, there are presented values of Cronbach's $\alpha(\mathrm{CA})$, composite reliability (CR), average variance extracted (AVE), and discriminant validity of the variables (constructs) in the form of the root of AVE (marked at a diagonal in Table 3).

Verification of reliability of the above indicators in relation to CTQ and Stress 1 is positive: Cronbach's $\alpha$ and composite reliability $(\mathrm{CR})$ reach values above .75. Average variance extracted also presents satisfactory values (above the required threshold of .50).

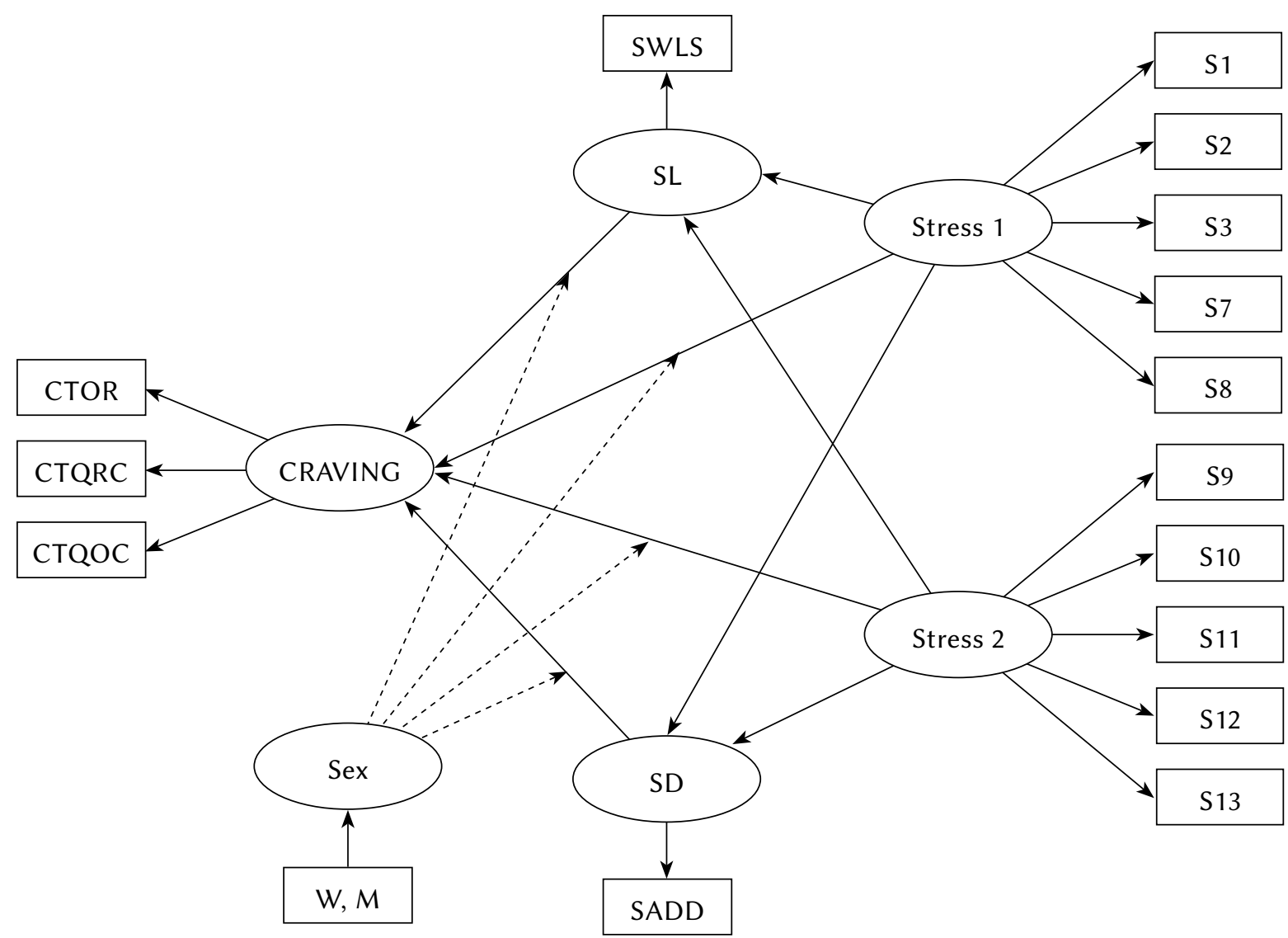

CRAVING: CTQR - Reward craving; CTQRC - Relief craving; CTQOC - Obsessive craving; Stress 1 - effective coping strategies; Stress 2 - ineffective coping strategies (S1-S13 - MiniCope scales); SD - severity of dependence (SADD); SL - satisfaction with life (SWLS), W - women, M - men.

Figure 1. General causal model of the relations of alcohol craving with strategies of coping with stress, severity of dependence, satisfaction with life, and sex. Own source. 
Table 2

Factor structure matrix of loadings and cross-loadings

Krzysztof Gąsior Agata Biedrzycka, Jan Chodkiewicz, Marcin Ziółkowski, Damian Czarnecki, Artur Juczyński, Katarzyna NowakowskaDomagała

\begin{tabular}{lcccccc}
\hline & CTQ & Stress 2 & Stress 1 & SD & SL & Sex \\
\hline CTQR & .83 & .21 & -.20 & .39 & -.21 & .18 \\
CTQRC & .78 & .33 & -.21 & .40 & -.27 & -.02 \\
CTQOC & .78 & .30 & -.25 & .42 & -.21 & .03 \\
S10 & .36 & .77 & -.25 & .40 & -.20 & -.02 \\
S11 & .32 & .79 & -.27 & .31 & -.27 & -.08 \\
S12 & .24 & .90 & .09 & .28 & -.12 & -.08 \\
S13 & .18 & .91 & -.11 & .25 & -.14 & -.19 \\
S1 & -.24 & -.21 & .89 & -.21 & .12 & -.13 \\
S2 & -.27 & -.22 & .87 & -.22 & .19 & -.09 \\
S3 & -.21 & -.05 & .91 & -.18 & .28 & .01 \\
SADD & .40 & .31 & -.18 & .78 & -.28 & .06 \\
SWLS & -.25 & -.20 & .18 & -.32 & .87 & -.01 \\
Sex & .07 & -.09 & -.09 & .07 & -.01 & .97 \\
\hline
\end{tabular}

Note. CTQ - Craving Typology Questionnaire; CTQR - Reward craving; CTQRC - Relief craving; CTQOC - Obsessive craving; Stress 1 - effective coping strategies; Stress 2 - ineffective coping strategies; SD - severity of dependence; SL - satisfaction with life. Own source.

Table 3

Cronbach's $\alpha(C A)$, composite reliability (CR), average variance extracted (AVE), and discriminant validity of the constructs

\begin{tabular}{lccccccccc}
\hline & CA & CR & AVE & CTQ & Stress 2 & Stress 1 & SD & SL & Sex \\
\hline CTQ & 0.79 & 0.80 & 0.70 & 0.84 & & & & & \\
Stress 2 & 0.61 & 0.77 & 0.46 & 0.35 & 0.68 & & & & \\
Stress 1 & 0.75 & 0.86 & 0.67 & -0.27 & -0.19 & 0.82 & & & \\
SD & 1.00 & 1.00 & 1.00 & 0.51 & 0.39 & -0.23 & 1.00 & & \\
SL & 1.00 & 1.00 & 1.00 & -0.28 & -0.23 & 0.20 & -0.36 & 1.00 & \\
Sex & 1.00 & 1.00 & 1.00 & 0.07 & -0.09 & -0.09 & 0.07 & -0.01 & 1.00 \\
\hline
\end{tabular}

Note. CA - Cronbach's $\alpha$ coefficients; CR - Composite reliability coefficients; AVE - Average variances extracted; CTQ - Craving Typology Questionnaire; Stress 1 - effective coping strategies; Stress 2 - ineffective coping strategies; SD - severity of dependence; SL - satisfaction with life. Own source.

The construct Stress 2 does not reach the criterion values of Cronbach's $\alpha$ and AVE but it is characterised by a satisfactory value of CR. As for discriminant validity, each of the variables (constructs) fulfils the necessary condition of the root of AVE, being higher than correlations with the other constructs (diagonal in Table 3).

In the next step, we determined characteristics of the structural model (scheme 2) together with assessment of its parameters ${ }^{1}$.

Variance inflation factor VIF (AFVIF) $=1.31$ does not exceed the value of 3.30 , which is recommended for "ideal" models. Thus, it may be concluded that there are no problems related to collinearity in the
Average path coefficient $(\mathrm{APC})=0.16, p<.001$

Average $R^{2}(\mathrm{ARS})=0.22, p<.001$

Average adjusted $R^{2}(\mathrm{AARS})=0.21, p<.001$

Average block VIF (AVIF) $=1.31$, acceptable if $\leq 5$, ideal $\leq 3.30$

Average full collinearity VIF $($ AFVIF $)=1.26$, acceptable if $\leq 5$, ideal $\leq 3.30$

Tenenhaus GoF $(\mathrm{GoF})=0.42$, small $\geq 0.10$, medium $\geq 0.25$, large $\geq 0.36$

Simpson's paradox ratio $(\mathrm{SPR})=0.85$, acceptable if $\geq 0.70$, ideal $=1.00$

$R^{2}$ contribution ratio $(\mathrm{RSCR})=0.98$, acceptable if $\geq 0.90$, ideal $=1.00$ 


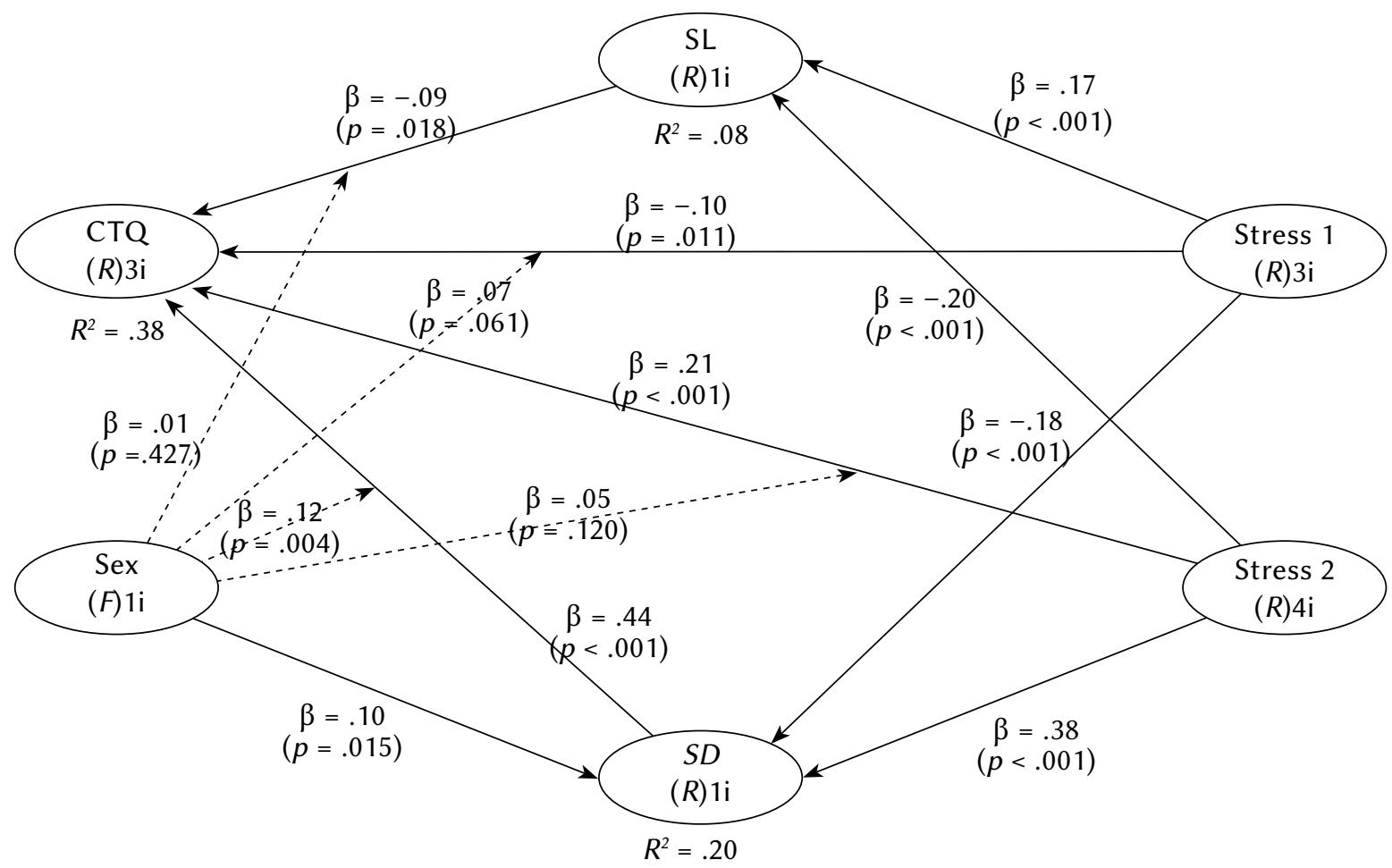

Alcohol craving and stress

Figure 2. Structural model of dependencies among latent variables: CTQ - Craving; Stress 1 - effective coping strategies; Stress 2 - ineffective coping strategies; $S D$ - severity of dependence; $\mathrm{SL}$ - satisfaction with life. Path coefficients and $p$ values $<.01$. Own source.

model. Also the Tenenhaus GoF indicator (.41) has significant values, which proves to be a good total fit of the internal model and the structural (external) one. Both the average path coefficient and the average and adjusted $R^{2}$ coefficients have satisfactory values. This also applies to the remaining experimental (as they are called by Kock) indicators, such as Simpson's paradox ratio.

The $R^{2}$ coefficient for the variable CRAVING (CTQ) has the value of .38, which may be assessed as moderate. The strongest relation with alcohol craving is displayed by severity of dependence $(\beta=.46)$. The constructs of Stress $1(\beta=-.10)$ and Stress 2 $(\beta=.21)$ are also related to alcohol craving in a significant but weaker way. The weakest relations occur for satisfaction with life $(\beta=-.08)$. Stress 1 and Stress 2 exert a stronger influence on life satisfaction, which may result indirectly in an influence on experiencing craving.

Severity of dependence is significantly related to strategies of reacting to stress; it strengthens ineffective strategies, and weakens the effective ones. It also becomes a mediator between coping strategies and the strength of experienced craving. The effect of the mediating influence exerted by severity of dependence is almost twice as high as the direct influence of coping strategies on alcohol craving (Table 4). The role of a mediator is also played by satisfaction with life, yet this influence is markedly weaker, though statistically significant. In the model submitted to verification, gender was defined as a moderating variable. It appeared to be significantly related to one pair of latent variables: severity of dependence $\rightarrow$ craving. This means that gender plays an important role; it moderates the relation between severity of dependence and strength of experienced alcohol craving. However, an explanation of this relation requires some additional analyses.

To sum it up, the evidence suggests that experiencing alcohol craving is first and foremost strengthened by severity of dependence and dominance of ineffective strategies of coping with stress (alcohol use, behavioural disengagement, venting emotions, distracting attention), whereas effective strategies of reacting to stress (active coping, planning, positive reframing) and satisfaction with life exert a hindering influence. Severity of dependence is an important mediator between strategies of coping and the strength of perceived and experienced craving. Gender constitutes an important variable that moderates the relation between severity of dependence and strength of craving.

\section{DISCUSSION AND CONCLUSIONS}

Stress plays a significant role in the beginning and development of a dependence, although this role is not thoroughly clear (Cierpiałkowska \& Ziarko, 2010). On the basis of the conducted research it turns 
Table 4

Direct, indirect and total effects of variables

\begin{tabular}{|c|c|c|c|c|c|c|c|}
\hline Effects & Variables & CTQ & Stress 1 & Stress 2 & SD & $\mathrm{SL}$ & Sex \\
\hline \multirow{5}{*}{ Direct effects } & Stress 1 & -.10 & & & -.18 & .17 & \\
\hline & Stress 2 & .21 & & & .38 & -.20 & \\
\hline & SD & .44 & & & & & \\
\hline & $\mathrm{SL}$ & -.09 & & & & & \\
\hline & Sex & & & & .10 & & \\
\hline \multirow{5}{*}{ Indirect effects } & Stress 1 & -.10 & & & & & \\
\hline & Stress 2 & .18 & & & & & \\
\hline & SD & & & & & & \\
\hline & $\mathrm{SL}$ & & & & & & \\
\hline & Sex & .04 & & & & & \\
\hline \multirow{5}{*}{ Total effects } & Stress 1 & -.20 & & & -.18 & .17 & \\
\hline & Stress 2 & .39 & & & .38 & -.20 & \\
\hline & SD & .44 & & & & & \\
\hline & $\mathrm{SL}$ & -.09 & & & & & \\
\hline & Sex & .04 & & & .10 & & \\
\hline
\end{tabular}

Krzysztof Gąsior, Agata Biedrzycka, Jan Chodkiewicz, Marcin Ziółkowski, Damian Czarnecki, Artur Juczyński, Katarzyna NowakowskaDomagała

Note. Abbreviations as in Table 3. Own source.

out that it has a significant role in the occurrence and strengthening of alcohol craving as well. The analysis of the obtained results indicates that there are varied dependencies between alcohol craving and strategies of reacting to stress. Only some of the Mini-Cope scales displayed significant relations with craving. In the previous studies in which the scale was used, those conducted among the addicted and in other groups, the occurrence of similar dependencies was observed. For example, in the studies by Terelak and Dzięgielewska (2011), alcoholics, after detox treatment, more often used such effective strategies of coping with stress as seeking social support, focusing on a problem, or growth of self-control. Yet, there is a lack of more thorough studies on dependencies between alcohol craving and coping strategies.

The present study revealed the existence of two tendencies of linking craving and its varied aspects with strategies of coping with stress. The first tendency, the clearly dominant one, suggests that the greater the inclination to react to stress with ineffective strategies, the stronger is the craving, especially in such symptoms as the need of relief or drinking-related obsessions and compulsions. These strategies include alcohol use, denial of problems, venting emotions, and behavioural disengagement. However, the analyses have shown that the dominant way of reacting to stress consists in striving for alcohol in order to seek relief and free oneself from negative feelings. The second tendency, the weaker one, is related to using effective strategies of coping with stress, especially active ones, which are based on planning and positive reframing. Generally speaking, when more active strategies are used by an addicted person, especially with regard to planning activities, a weaker craving will be experienced, particularly in case of its obsessive-compulsive aspect. It is worth drawing attention to those strategies of reacting to stress that did not display any significant dependencies or correlations with alcohol craving. What is most puzzling is the lack of any dependencies in subjects with good family and friend support. These strategies are referred to as exceptionally important in the process of therapy for the addicted (compare: Monti \& Rohsenow, 1999).

The studies conducted by Grüsser, Mörsten, and Flor (2006) proved relations between stress and alcohol craving. It is suggested that the beginning of a dependence is accompanied by a decrease in the motivational role of alcohol as a rewarding stimulus and an increase in negative expectations of drinking effects. They are related to a growth of non-adaptive strategies of coping with stress. In the study by Grüsser, positive coping strategies did not differentiate alcoholics and non-alcoholics. Negative strategies of coping with stress, though correlated with craving, were not a good predicator of its growth and further drinking. The present study confirmed significant correlations between non-functional coping strategies and alcohol craving. The structural model indicated significant causal relations between these variables. It appears that both severity of dependence and negative strategies of coping with stress make 
craving stronger. Thus, both the indicators may be good predicators of alcohol craving, while effective strategies and satisfaction with life play a role as factors that prevent craving experiences.

The present research has also shown that severity of dependence is a significant mediator between ways of coping with stress and perceived and experienced alcohol craving. The relation between alcohol craving and severity of dependence, and the direction of this relation that is consistent with the one obtained in the current research, have already been noted in specialized literature (Yoon et al., 2006). Together with the dependence starting and deepening, the ineffective strategies of coping with stress become strengthened and the effective ones become weakened. This conclusion is an indirect confirmation of the hypothesis about changes in motivational processes that appear in addicted persons in the course of the disease. As it is suggested in the studies by Grüsser et al. (2006), in the case of occasional drinking and in the initial stages of a dependence, alcohol is basically a motivational stimulus related to seeking a reward. Motivational processes are not deeply disordered yet. Deepening of the dependence leads to pathology of motivational processes, especially those related to adaptive competencies and skills. Furthermore, experiencing negative consequences of drinking does not diminish alcohol craving but even heightens it. Thus, it may be justified to suppose that the influence of alcohol as a rewarding factor becomes weaker, and other aspects of craving related to obsessions and compulsions or to the desire of relief become stronger. Participants in this study have a long history of the development of their dependence (the average period of dependence is 14.70 years). A strong relation between severity of dependence and growth of ineffective strategies of reacting to stress is visible in this group.

The present study indicated the existence of gender-related differences with regard to experiencing craving in the context of reactions to stress. In men, contrary to women, such craving components as the desire of relief and obsessions/compulsions are more strongly related to alcohol use and behavioural disengagement, whereas in women the need of reward (thrill seeking and experiencing states of stupor) that is linked with drinking as well as obsessive thoughts about drinking are more strongly related to venting emotions. Women and men do not basically differ with regard to linking craving with effective strategies of coping with stress. It is worth noting that in women the relation between craving and orientation toward religion is stronger (a statistical trend). These conclusions confirm some earlier reports about differences in the beginning and development of alcohol dependence in women and men (Gąsior, 2006).

In the present study, satisfaction with life was also significantly related to craving. The correlations between these two variables were negative and weak.
The study by Ogińska-Bulik (2014) showed that there is a generally low level of satisfaction with life in the addicted, yet strong relations between life satisfaction and resilience indicate that they could play a role in the process of addiction treatment. Possible gender-related differences that regard links between satisfaction with life and alcohol craving are not thoroughly explained. This issue demands some further studies, especially because some previous ones also seem to indicate the existence of gender-related differences between life quality and reactions to stress (Mroczkowska \& Białkowska, 2014).

To sum up the research results, one may point to a few significant therapeutic implications:

- The selection of a therapy with regard to coping with stress should depend on severity of dependence, the level of pathologisation of motivational processes, and presence of resources that are related to reacting to stress. In the initial phase of the therapy, working on the problem of craving may be focused on its reactive aspects (e.g. the sight and smell of alcohol, being next to other persons drinking alcohol - the so-called direct craving stimulants) and reducing ineffective ways of coping with stress. In the further stages of the therapy it is important to carry out a deepened work on craving in the context of relapses and developing effective ways of coping with stress.

- It is advisable that a therapeutic programme consider gender-related differences with regard to varied aspects of craving and reactions to stress. For women, it is necessary to focus greater attention on problems with coping with emotions (especially anxiety and dejection) and problems with their emotional expression. For men, greater attention should be focused on control of impulsive behaviours and anger (because of the relations between craving that results from the desire for relief and drinking alcohol as a coping strategy).

This study has some limitations. First of all, it was cross-sectional. In the future, it is worth examining how the character and intensity of alcohol craving change in the course of abstinence of the addicted. It is also necessary to balance the number of participants with regard to their gender. This will allow for a closer look at the differences in dependencies between craving and ways of reacting to stress. The methods of statistical analysis based on PLS that were used in the study also demand some further verification.

While planning further research it is worth considering, to a larger extent, the dynamics of mutual influence of factors that prevent an increase in alcohol craving. If craving is present in the life of recovering alcoholics independently of a period of abstinence, it becomes extremely important to determine not only factors that may activate and strengthen craving, but also factors that may diminish it.
Alcohol craving and stress 
The study was carried out within the research project B141180000050.03 "Experiencing alcohol craving by addicted persons. Polish adaptation of measurement tools and their promotion", which was financed by the State Agency for Solving Alcohol Problems.

\section{ENDNOTES}

Krzysztof Gąsior, Agata Biedrzycka, Jan Chodkiewicz, Marcin Ziółkowski, Damian Czarnecki, Artur Juczyński, Katarzyna NowakowskaDomagała

1 Construction, description, and interpretation of the parameters that were used in the assessment of the PLS-PM model in the WarpPLS. 5.0 programme are provided in the manual: Kock (2015). WarpPLS 5.0 User manual. www.scriptwarp.com. Compare also: Kock and Lynn (2012). Below there is a concise description of the experimental parameters (Kock, 2015, p. 52):

The index SPR (Simpson's paradox ratio) is a measure of the extent to which a model is free from instances of Simpson's paradox. An instance of Simpson's paradox occurs when a path coefficient and a correlation associated with a pair of linked variables have different signs. The SPR index is calculated by dividing the number of paths in a model that are not associated with instances of Simpson's paradox by the total number of paths in the model.

The RSCR index is a measure of the extent to which a model is free from negative $R^{2}$ contributions, which occur together with instances of Simpson's paradox. This index is similar to the SPR. The key difference is that it is calculated based on the actual values of the $R^{2}$ contributions, not on the number of paths where these contributions have specific signs. The RSCR index is calculated by dividing the sum of positive $R^{2}$ contributions in a model by the sum of the absolute $R^{2}$ contributions (be they negative or positive) in the model.

\section{REFERENCES}

Abd-El-Fattah, S. M., \& Fakhroo, H. A. (2012). The relationship among paternal psychological control and adolescents' perfectionism and self-esteem: a partial least squares path analysis. Psychology, 3, 428-439.

Altman, J., Everitt, B. J., Glautier, S., Markou, A., Nutt, D., Oretti, R., Philips, G. D., \& Robbins, T. (1996). The biological, social and clinical bases of drug addiction: commentary and debate. Psychopharmacology, 125, 285-345.

Berglund, E., Lystsy, P., \& Westerling, R. (2013). Adherence to and beliefs in lipid-lowering medical treatments: a structural equation modeling approach including the necessity-concern framework. Patient Education and Counseling, 91, 105-112.
Cappell, H. H. (1972). Alcohol and tension reduction: A review. Quarterly Journal of Study on Alcohol, 12, 33-34.

Carver, C. S., Scheier, M. F., \& Weintraub, J. K. (1989). Assessing coping strategies: a theoretically based approach. Journal of Personality and Social Psychology, 56, 267-283.

Casey, M., Adamson, G., Shevlin, M., \& McKinney, A. (2012). The role of craving in AUDs: Dimensionality and Differential Functioning in the DSM-5. Drug and Alcohol Dependence, 125, 75-80.

Chaplin, T. M., Hong, K., Bergquist, K., \& Sinha, R. (2008). Gender differences in response to emotional stress: an assessment across subjective, behavioral, and physiological domains and relations to alcohol craving. Alcoholism: Clinical and Experimental Research, 32, 1242-1250.

Cheng, H., \& Furnham, A. (2003). Attributional style and self-esteem as predictors of psychological well being. Counseling Psychology Quarterly, 16, 121-130.

Chodkiewicz, J. (2012). Odbić się od dna? Rola jakości życia w przebiegu i efektach terapii osób uzależnionych od alkoholu [To strike against the bottom and begin to rise? the role of life quality in the course and effects of a therapy of the alcohol addicted]. Łódź: Wydawnictwo Uniwersytetu Łódzkiego.

Chodkiewicz, J. (2013). Motywacja do leczenia i utrzymywania abstynencji a ukończenie terapii przez mężczyzn uzależnionych od alkoholu [Motivation to treatment and maintaining abstinence as related to completing a therapy by alcohol-addicted men]. Alkoholizm i Narkomania, 26, 119-136.

Chodkiewicz, J. (2014). Głód alkoholu - konceptualizacja, wybrane modele i metody pomiaru [Alcohol craving - a conceptualization, selected models and measurement methods]. Alkoholizm i Narkomania, 27, 265-272.

Chodkiewicz, J., Nowakowska-Domagała, K., Ziółkowski, M., Czarnecki, D., Gąsior, K., Juczyński, A., \& Biedrzycka, A. (in preparation). Polska adaptacja Kwestionariusza Typologii Gtodu Alkoholu Martinottiego $i$ wsp. [Polish Adaptation of the Craving Typology Questionnaire by Martinotti et al.].

Cierpiałkowska, L., \& Ziarko, M. (2010). Psychologia uzależnień - alkoholizm [Psychology of Addictions - Alcoholism]. Warszawa: PWN.

Conger, J. J. (1951). The effects of alcohol on conflict behavior in the albino rat. Quarterly Journal of Study on Alcohol, 1, 1-29.

Daeppen, J. B., Krieg, M. A., Burnand, B., \& Yersin, B. (1998). MOS-SF-36 in evaluating health-related quality of life in alcohol-dependent patients. American Journal of Drug and Alcohol Abuse, 24, 685-694.

De Witt, H. (1996). Priming effects with drugs and other reinforcers. Experimental and Clinical Psychopharmacology, 4, 5-10. 
Di Chiara, G. (1998). A motivational learning hypothesis of the role of mesolimbic dopamine in compulsive drug use. Journal of Psychopharmacology, 12, 54-67.

Di Chiara, G. (1995). The role of dopamine in drug abuse viewed from the perspective of its role in motivation. Drug and Alcohol Dependence, 38, 95-137.

Diener, E. (1984). Subjective Well-being. Psychological Bulletin, 95, 542-575.

Diener, E., Emmons, R. A., Larsen, R. J., \& Griffin, S. (1985). The Satisfaction with Life Scale. Journal of Personality Assessment, 49, 71-75.

Diener, E., \& Lucas, R. E. (2006). Beyond the hedonic treadmill: revising the adaptation theory of well-being. American Psychologist, 61, 305-314.

Donovan, D., Mattson, M., Cisler, R., Longabaugh, R., \& Zweben, A. (2005). Quality of life as an outcome measurement in alcoholism treatment research. Journal of Studies on Alcohol, 15, 119-139.

Etinger, D., Šehanović, J., \& Ribić, A. (2014). Measuring the success of e-library implementation: students perceptions and use. In: D. Barković \& B. Runzheimer (eds.), Interdisciplinary Management Research X (pp. 973-985). Osijek: Josip Juraj Strossmayer University of Osijek (https://bib.irb. hr/datoteka/698881.Etinger-IMR_X_.pdf).

Espozito Vinzi, V., Chin, W.W., Henseler, J., \& Wang, H. (2010). Handbook of Partial Least Squares Concepts, Methods and Applications. Berlin, Heidelberg: Springer-Verlag (http://www. springer.com/ series/7286).

Gąsior, K. (2006). Typy alkoholizmu kobiet. Badania, interpretacja psychologiczna, psychoterapia [Types of alcoholism in women. Studies, psychological interpretation, psychotherapy]. Kielce: Kaligraf.

Grüsser, S. M., Mörsen, C. P., \& Flor, H. (2006). Alcohol craving in problem and occasional alcohol drinkers. Alcohol \& Alcoholism, 41, 421-425.

Hair, J. F., Hult, G. T. M., Ringle, C. M., \& Sarstend, M. (2014). A primer on partial least squares structural equation modeling (PLS-SEM). Los Angeles: Sage Publications Inc.

Hamidizadeh, A., Koolivand, H., \& Hajkarimi, F. (2014). Is workaholism antecedent of burn out? European Journal of Academic Essays, 1, 1-9.

Hodgson, R. J., Stockwell, T. R., \& Rankin, H. J. (1979). Can alcohol reduce tension? Behaviour Research and Therapy, 17, 459-466.

Hughes, J. R., \& Bickel, W. K. (1997). Modeling drug dependence behaviors for animals and human studies. Pharmacology Biochemistry and Behavior, 57, 413-417.

Juczyński, Z. (2009). Narzędzia pomiaru w promocji i psychologii zdrowia [Measurement tools in health promotion and psychology]. Warszawa: Pracownia Testów Psychologicznych PTP.

Juczyński, Z., \& Ogińska-Bulik, N. (2009). Narzędzia pomiaru stresu i radzenia sobie ze stresem [Tools for measuring stress and coping]. Warszawa: Pracownia Testów Psychologicznych PTP.

Januszewski, A. (2011). Modele równań strukturalnych w metodologii badań psychologicznych. Problematyka przyczynowości w modelach strukturalnych i dopuszczalność modeli [Structural equation models in methodology of psychological research]. Studia z Psychologii w KUL, 17, 213-245.

Kock, N. (2011). Using WarpPLS in e-collaboration studies: Mediating effects, control and second order variables, and algorithm choices. International Journal of e-Collaboration, 7, 1-13.

Kock, N. (2015). WarpPLS 5.0, User manual. Laredo Texas: ScriptWarp Systems.

Kock, N., \& Lynn, G. S. (2012). Lateral colinearity and misleading results in variance-based sem: an illustration and recommendations. Journal of the Association for Information Systems, 13, 546-580.

Konarski, R. (2009). Modele równań strukturalnych. Teoria i praktyka [Structural equation models. Theory and practice]. Warsaw: PWN.

Koob, G. F. (1996). Hedonic valence, dopamine and motivation. Molecular Psychiatry, 1, 186-189.

Kostowski, W. (2005). Uzależnienia - podstawowe pojęcia i teorie [Addictions - basic notions and theories]. Psychiatria, 2, 61-76.

Lazarus, R. S. (1965). Towards the understanding and effective treatment of alcoholism. South African Medical Journal, 39, 736-741.

Lazarus, R. S., \& Folkman, S. (1984). Stress, appraisal and coping. New York: Spronger.

Le, A. D., Quan, B., Juzytch, W., Fletcher, P. J., Joharchi, N., \& Shaham, Y. (1998). Reinstatement of alcohol-seeking by priming injections of alcohol and exposure to stress in rats. Psychopharmacology, 135, 169-174.

Litman, J. A. (2006). The COPE inventory: Dimensionality and relationships with approach- and avoidance-motives and positive and negative traits. Personality and Individual Differences, 41, 273-284.

Marlatt, G. A., \& Gordon, J. R. (1985). Relapse prevention: maintenance strategies in the treatment of addictive behavior. New York: Guilford Press.

Martinotti, G., Di Nicola, M., Tedeschi, D., Callea, A., Di Giannantonio, M., \& Janiri, L. (2013). Craving Typology Questionnaire (CTQ): A scale for alcohol craving in normal controls and alcoholics. Comprehensive Psychiatry, 54, 925-932.

McIntosh, C. N., Edwards, J. R., \& Antonakis, J. (2014). Reflections on partial least squares path modeling. Organizational Research Methods, 17, 210-251. doi: 10.1177/1094428114529165

Mendelson, J. H., Scholar, M., Mello, N. K., Teoh, S. K., \& Scholar, J. W. (1998). Cocaine tolerance: behavioral, cardiovascular, and neuroendocrine function in men. Neuropsychopharmacology, 18, 263-271.

Modell, J. G., Glaser, F. B., Mountz, J. M., Schmaltz, S., \& Cyr, L. (1992). Obsessive and compulsive char-
Alcohol craving and stress 
Krzysztof Gąsior, Agata Biedrzycka, Jan Chodkiewicz, Marcin Ziółkowski, Damian Czarnecki, Artur Juczyński, Katarzyna NowakowskaDomagała acteristics of alcohol abuse and dependence: quantification by a newly developed questionnaire. Alcoholism: Clinical and Experimental Research, 16, 266-271.

Monti, P. M., \& Rohsenow, D. J. (1999). Coping-skills training and cue-exposure therapy in the treatment of alcoholism. Alcohol Research \& Health, 23, 107-115.

Morgan, M. Y., Landron, F., \& Lehert, P. (2004). Improvement in quality of life after treatment for alcohol dependence with acamprosate and psychosocial support psychosocial support A nontherapeutic intervention that helps a person cope with stressors at home or at work. See Companionship, Most significant other. Alcoholism, Clinical and Experimental Research, 28, 64-77.

Mroczkowska, D., \& Białkowska, J. (2014). Style radzenia sobie ze stresem jako zmienne determinujące jakość życia młodych dorosłych [Styles of coping with stress as variables that determine life quality in young adults]. Medycyna Ogólna i Nauki o Zdrowiu, 20, 265-269.

Myers, D. G., \& Diener, E. (1995). Who is happy? Psychological Science, 1, 10-18.

Nowakowska-Domagała, K., Chodkiewicz, J., Ziółkowski, M., Czarnecki, D., Gąsior, K., Juczyński, A., \& Biedrzycka, A. (in press). Polska adaptacja Skali Yale-Brown Obsesyjno-Kompulsyjnego Intensywnego Picia [Polish Adaptation of the Yale - Brown Obsessive Compulsive Scale Modified to Reflect Obsessions and Compulsions Related to Heavy Drinking].

Ogińska-Bulik, N. (2014). Prężność psychiczna a zadowolenie z życia osób uzależnionych od alkoholu [Mental resilience and life satisfaction in alcohol-addicted persons]. Alkoholizm i Narkomania, 27, 319-324.

Przechlewski, T. (2011). Akceptacja oprogramowania Open Source. Metody i modele informatyki ekonomicznej [Acceptance of Open Source Software. Methods and Models of Economic Informatics]. http://pinkaccordions.homelinux.org/staff/tp/ Pubs/aoos/aoos.pdf

Raistrick, D. S., Dunbar, G., \& Davidson, R. J. (1983). Development of a questionnaire to measure alcohol dependence. British Journal of Addiction, 78, 89-95.

Ryff, C. D. (1989). Happiness is everything, or i sit? Explorations on the meaning of psychological well-being. Journal of Personality and Social Psychology, 57, 1069-1081.

Samson, H. H. (1986). Initiation of ethanol reinforcement using a sucrose-substitution procedure in food- and water-sated rats. Alcoholism: Clinical and Experimental Research, 10, 436-442.

Sinha, R. (2013). Modeling relapse situations in the human laboratory. Current Topics in Behavioral Neurosciences, 13, 379-402. doi: 10.1007/7854_2011_150
Sinha, R., Fox, H., Hong, K., Bhagwagar, Z., \& Siedlarz K. (2009). Enhanced negative emotion and alcohol craving, and altered physiological responses follow in stress and cue exposure in alcohol dependent individuals. Neuropsychopharmacology, 34, 1198-1208.

Skinner, M. D., \& Aubin, J. H. (2010). Craving's place in addiction theory: Contributions of the major models. Neuroscience and Biobehavioral Reviews, 34, 606-623.

Stewart, J. (2000). Pathways to relapse: The neurobiology of drug and stress-induced relapse to drug-taking. Journal Psychiatry Neuroscience, 25, 125-136.

Tenenhaus, M., Esposito Vinzi, V., Chatelin, Y. M., \& Lauro, C. (2005). PLS path modeling. Computational Statistics and Data Analysis, 48, 159-205.

Tiffany, S. T., \& Conklin, C. A. (2000). A cognitive processing model of alcohol craving and compulsive alcohol use. Addiction, 95 Suppl. 2, 145-153.

Terelak, J., \& Dzięgielewska, J. (2011). Strategie radzenia sobie ze stresem a skuteczność terapii uzależnień alkoholików [Strategies of coping with stress and effectiveness of dependence therapy for alcoholics]. Seminare, 29, 105-122.

Verheul, R., Van Den Brink, W., \& Geerlings, P. (1999). A three-pathway psychobiological model of craving for alcohol. Alcohol and Alcoholism, 34, 197-222.

Volk, R. J., Steinbauer, S. B., \& Cass, A. R. (1997). Alcohol use disorders, consumption patterns, and health-related quality of life of primary care patients. Alcoholism, Clinical and Experimental Research, 21, 899-905.

Wilson, V. E., \& Djamasbi, S. (2012). Interpersonality and Online Persuasion. Proceedings of JAIS Theory Development Workshop. Sprouts: Working Papers on Information Systems, 12, 1-2 (http://digitalcommons.wpi.edu/uxdmrl-pubs/1).

Wilson, V. E., Sheetz, S. D., Djamasbi, S., \& Webber, J. (2014). Testing the Group Task Demands-Resources Model among IT Professionals. Twentieth Americas Conference on Information Systems, Savannah (http://digitalcommons.wpi.edu/uxdmrl-pubs).

Wolffgramm, J., \& Heyne, A. (1995). From controlled drug intake to loss of control: the irreversible development of drug addiction in the rat. Behavior Brain Research, 70, 77-94.

Yoon, G., Kim, S. W., Thuras, P., Grant, J. E., \& Westermeyer, J. (2006). Alcohol craving in outpatients with alcohol dependence: rate and clinical correlates. Journal Study on Alcohol, 67, 770-777.

Ziółkowski, M. (1999). Ocena skuteczności farmakoterapii w zapobieganiu nawrotowi picia u mężczyzn uzależnionych od alkoholu [The assessment of effectiveness of pharmacotherapy in preventing drinking relapse in alcohol-addicted men]. Praca habilitacyjna. Bydgoszcz: Wydawnictwo Akademii Medycznej im. Ludwika Rydygiera. 